\title{
Analysis of the modified rankin scale in randomised controlled trials in acute stroke: a systematic review
}

\author{
Aimie Nunn ${ }^{1}$, Laura Gray ${ }^{2,3 *}$ \\ From 3rd International Clinical Trials Methodology Conference \\ Glasgow, UK. 16-17 November 2015
}

\begin{abstract}
Background
Historically, trials in acute stroke have largely been unable to show benefit of new interventions. Trials have previously favoured dichotomous analysis of outcome measures employing an ordinal scale, such as the Modified Rankin Scale (mRS). In 2007, the OAST Collaboration showed that preserving the ordinal nature of these scales increased statistical power, recommending the use of ordinal logistic regression where proportional odds could be assumed. A systematic review of trials and protocols published since 2007 was conducted to re-evaluate statistical methods used and assess whether practice has changed.
\end{abstract}

\section{Methods}

Searches of electronic databases identified trials published between Jan 2007 and July 2014 in acute ischaemic stroke using an ordinal measure of dependency as the primary outcome. Published protocols were also identified to evaluate proposed statistical analyses.

\section{Results}

Forty-two RCT results publications were identified. The majority of studies used a dichotomous analysis (25, $59.5 \%)$, eight (21.4\%) retained the ordinal scale and nine (19.0\%) used another type of analysis (two of which used a sliding dichotomy). Sixteen published protocols were identified, nine $(56.3 \%)$ of which intend to use an ordinal method of analysis. Six (37.5\%) intend to use a dichotomous analysis and one trial a sliding dichotomy (6.3\%).

\section{Conclusions}

Trials published since 2007 still favour dichotomous analyses over ordinal. Assessment of ongoing trial protocols shows that ordinal analyses are being incorporated more often, although trials with a published protocol

${ }^{2}$ Department of Health Sciences, University of Leicester, Leicester, UK Full list of author information is available at the end of the article may reflect a biased sample of all trials. Stroke trials, where appropriate, should retain the ordinal nature of dependency scales.

\section{Authors' details}

${ }^{1}$ MRC Clinical Trials Unit, University College London, London, UK. ${ }^{2}$ Department of Health Sciences, University of Leicester, Leicester, UK. ${ }^{3}$ Leicester Clinical Trials Unit, University of Leicester, Leicester, UK.

Published: 16 November 2015

doi:10.1186/1745-6215-16-S2-P130

Cite this article as: Nunn and Gray: Analysis of the modified rankin scale in randomised controlled trials in acute stroke: a systematic review. Trials 2015 16(Suppl 2):P130.

\footnotetext{
Submit your next manuscript to BioMed Central and take full advantage of:

- Convenient online submission

- Thorough peer review

- No space constraints or color figure charges

- Immediate publication on acceptance

- Inclusion in PubMed, CAS, Scopus and Google Scholar

- Research which is freely available for redistribution

C Biomed Central

C 2015 Nunn and Gray This is an Open Access article distributed under the terms of the Creative Commons Attribution License (http:// creativecommons.org/licenses/by/4.0), which permits unrestricted use, distribution, and reproduction in any medium, provided the original work is properly cited. The Creative Commons Public Domain Dedication waiver (http://creativecommons.org/publicdomain/ zero/1.0/) applies to the data made available in this article, unless otherwise stated. 